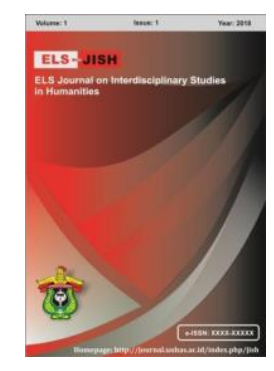

ELS-JISH

ELS Journal on Interdisciplinary Studies on Humanities

Volume 3 Issue 1, 2020

ISSN (print) : 2621-0843

ISSN (online) : 2621-0835

Homepage : http://journal.unhas.ac.id/index.php/jish

\title{
Engagement During Storybook Reading Promotes Indonesian Children's English Vocabulary Acquisition
}

\author{
Rizka Junhita Rahma Wanodya ${ }^{1}$, Nur Arifah Drajati ${ }^{2}$, Sri Samiati Tarjana $^{3}$ \\ 1rizkajunhita@student.uns.ac.id
}

\begin{abstract}
The purpose of this study is to explore the engagement of parents-child during the implementation of storybook reading to promote Indonesian children's English vocabulary acquisition. The researcher uses questionnaire and interview to collect the data. There are 81 respondents who fulfil the questionnaire. The researcher applies an in-depth open ended interview. The result shows that children acquire new English vocabularies through the implementation of storybook reading by parents from home-based activity. The researcher uses Narrative Inquiry as the research methodology. The implication of this study to increase the parents' awareness on the benefit of implementing storybook reading to promote children's English vocabulary acquisition. The other implication is guiding parents to create engagement to reach the goals.
\end{abstract}

Keywords: Engagement, English vocabulary acquisition, Narrative inquiry, Storybook reading.

How to cite: Wandoya, R. J. R., Drajati, A. N., \& Tarjana, S. S. (2020). Engagement During Storybook Reading Promotes Indonesian Children's English Vocabulary Acquisition. ELS Journal on Interdisciplinary Studies in Humanities, 3(1), 66-74. DOI:

http://dx.doi.org/10.34050/els-jish.v3i1.9680

\section{Introduction}

In Indonesia, English language is treated as one of the most important foreign language to be learnt. Indonesian children mostly start to learn English formally from elementary grades and up. Study about introducing English under elementary grades are rarely to be found. Most of preschool grades in Indonesia did not insert English as one of the lesson at school. There are some benefits by introducing English to Indonesian young children (golden ages). One of the benefit is gaining children's interest towards the existence of another language. Children becomes familiar with English vocabularies. Moreover, the International Children Foundation (UNICEF) also shows some benefits of introducing English from the very young age. Children had their most rapid language development in their first seven (7) years of life. By introducing English from under age seven, it is easier to help children to acquire second language.

${ }^{1,2,3}$ Universitas Sebelas Maret, Indonesia. 
From the issue above, family needs to take a role in introducing English to their young children. Family becomes the first influencer and resources for their children (Saracho \& Spodek, 2010). This can be means that by family's involvement, children had their easier way to acquire new English vocabularies. The involvement of family develops children's language need (Saracho, 2016). Storybook reading can be one of the tools to start introducing English vocabularies to young children from home-based family interaction. However, during the parents-child interaction of storybook reading activity, engagement may exist or not. The researcher uses two kinds of gaps. The two gaps are empirical gaps and methodological gaps. The researcher uses empirical gaps because study about the engagement of parents-child during storybook reading promote Indonesian children's English vocabulary acquisition is rarely to be found. The researcher uses methodological gaps because this study use narrative inquiry which is still limited in Indonesia. Thus, a question will appear: "Does the engagement of parents-child during storybook reading promote Indonesian children's English vocabulary acquisition?".

Storybook reading is a cooperative negotiation of textual meaning by reader and listener (Saracho \& Spodek, 2010). When children are listening to stories, children grow their vocabulary development and other areas of literacy (Elley1989, 2013). By understanding the stories, it promotes the vocabulary acquisition of second language learners. However, the first language will scaffold in building the knowledge and acquisition of new language (English). Elley (1980,1989) and Elley and Mangubhai (1983) conducted a study about second language vocabulary acquisition of children who listens to stories. The findings of the study showed that there is rapid growth in children's English vocabulary development. Elley (1980) added that there are three factors that influence vocabulary acquisition: (1) the frequency of words occurrence in the story, (2) the amount of help that the context offered, (3) the frequency of picture and words in the story.

Lambert (1991) conducted another similar study about second language learners who listens to English stories. The findings of the study showed that children had their gains towards English vocabulary acquisition, specifically when children were scaffold during the storybook reading activity. The scaffold here means that children needs help from the adult (it can be parents or teacher) to create a good understanding of the story. Thus, Elley (1991) assumed that children learn vocabularies when they repeatedly interact with stories.

Children's literature has an important effect on children's intellectual and emotional development (Kiefer, 2004). Children's literature provides awareness towards education, socialization, and communicative goals (Landt, 2006; Louie, 2006). Boutte et al. (2008) described three standards in choosing the children's literature books. The first requirement is that the children's literature books should include the early childhood education content and skills. The second requirement is that the children's literature books should contain imagination, fantasy, and humor. The third requirement is that the children's literature books should contain characters, moral values, and life lesson. Thus, the literature books, whether fiction or non-fiction may help the children to encounter the 
children's emotional relationship (Kiefer 2004). Presently, the field of children's literature covers numerous genres including $A B C$ and counting books, nursery rhymes and poetry collections, picture storybooks, novels, and non-fiction.

Norton and Norton (2007) provided the following genres of the children's literature: (1) traditional literature, (2) modern fantasy, (3) contemporary realistic fiction, (4) information books, and (5) poetry. Fables, myths, legends, folktales, fairy tales, hero tales and other story are included as the traditional literature. Meanwhile, the modern fantasy is a genre that requires the imagination. This type of literature has stories with place, people, creatures and events that could not be existed like an animal talking. Contemporary realistic fiction is a genre where the story reflects the people who live in contemporary world. Thus, the characters may be exaggerated and the plots may be preposterous. This kind of literature shows the reality that the story could have happened but it is mostly impossible. The next genre is information books. Information books may be consisted from some subjects, such as: history, animals, plants, geography, etc.). The last genre is poetry. Poetry provides enjoyment but make children aware about themselves.

Table 1. Selection criteria for narrative and information books (Saracho, 2018) Narrative Books Information Books

\begin{tabular}{|c|c|}
\hline $\begin{array}{l}\text { Have believable characters but should } \\
\text { ot be stereotyped. }\end{array}$ & Be accurate and \\
\hline $\begin{array}{l}\text { Be straightforward to help children to } \\
\text { understand the story. }\end{array}$ & $\begin{array}{l}\text { Have simple formats with attractive } \\
\text { illustration. }\end{array}$ \\
\hline $\begin{array}{l}\text { Use characters' language, } \\
\text { conversations, and ideas that reflect } \\
\text { the situation. }\end{array}$ & $\begin{array}{l}\text { Present information that represents } \\
\text { scientific knowledge. }\end{array}$ \\
\hline $\begin{array}{l}\text { timulating and } \\
\text { pleasing to motivate the } \\
\text { teract with the books. }\end{array}$ & $\begin{array}{l}\text { Be visually stimulating and aesthetically } \\
\text { pleasing to motivate the children to } \\
\text { interact with the books. }\end{array}$ \\
\hline $\begin{array}{l}\text { Encourage the children to read by } \\
\text { themselves several times. }\end{array}$ & $\begin{array}{l}\text { Encourage the children to read by } \\
\text { themselves several times. }\end{array}$ \\
\hline $\begin{array}{l}\text { Interesting for both male and female } \\
\text { children. }\end{array}$ & $\begin{array}{l}\text { Interesting for both male and female } \\
\text { children. }\end{array}$ \\
\hline $\begin{array}{l}\text { Reflect their home environment and } \\
\text { daily lives. }\end{array}$ & $\begin{array}{l}\text { Reflect their home environment and } \\
\text { daily lives. }\end{array}$ \\
\hline $\begin{array}{l}\text { Have a story structure, problem, } \\
\text { solving, and solution. }\end{array}$ & Be familiar to the children. \\
\hline $\begin{array}{l}\text { Focus on understanding the main } \\
\text { characters. }\end{array}$ & Us \\
\hline $\begin{array}{l}\text { Uses readers' knowledge to guide } \\
\text { their comprehension of the story. }\end{array}$ & $\begin{array}{l}\text { ate information about a } \\
\text { c. }\end{array}$ \\
\hline Have fictional and traditional narrative & Rely on expository text structure. \\
\hline
\end{tabular}

Young children might found many unfamiliar structure of the text or new foreign vocabulary, thus they need adult's assist to build the bridge or to overcome the gap between their own world and what presented in the storybook (Bus, 2003). The benefit of implementing storybook reading is strongly depending on how parents supported their children. Parents need to find many ways to catch the children's interest towards the book (Baker, 2003). 
When the parents secure with the activity, parents will automatically put their sensitivity and supportiveness to make the activity become a successful one. Children usually anticipate for their parents' behavior during the storybook reading activity to fulfill the children's need.

The measurement of children's attentiveness, maternal interventions to control the child's behavior and child's responsiveness are used to show the secure and insecure engagement between parents and children (Bus \& Van ljzendoorn, 1997). Thus, if adults fail to create engagement during storybook reading activity, children become less attractive.

\section{Method}

This research was exploring the engagement of parents-child during storybook reading promote Indonesian children's English vocabulary acquisition. In this research the researcher used qualitative research narrative inquiry. Narrative inquiry is a way of doing research that focused on the stories about self-lives. These stories are about the experiences of live; the meaning that was made from the events we live or imagine in our future lives (Barkhuizen, 2014).

Participants in this study were two parents who aware to their early children's English vocabulary acquisition through storybook reading implementation. The two parents are one father and one mother with the children age range of four to five years old. Both parents had their English language background.

The researcher use questionnaire and interview to collect the data. The researcher collected the information from 81 participants of the questionnaire. The researcher use interview for the oral narrative data by conducting semistructured interview.

In this study, the steps of conducting the research are as follows. The researcher asked the participants to fulfil the questionnaire to reveal whether the participants met the appropriate criteria or not. Afterwards, in-depth interviews were conducted to explore the engagement between parents and children during the English storybook reading and to reveal whether the engagement creates children's new English vocabulary acquisition.

To analyze the data, researcher uses thematic analysis. Thematic analysis is used to compare narratives in data set and highlight individual differences (Barkhuizen, 2014). The analysis of interview uses transcription, coding and analysis. Transcription is essential to deal with findings. Selective coding is for analysis to emphasize the relationship between the participant's experiences. The analysis explored in detail the stories in term of its content containing who, where, and when which elaborated into the context of its story and Story (Barkhuizen, 2014). All names in the data are pseudonyms.

\section{Results}

For the findings, the researcher chooses a short story which relates to the research purpose. The story explains about the engagement of parents-child during storybook reading promote Indonesian children's English vocabulary 
acquisition. The stories are from the result of the parents' in-depth interview.

\title{
3.1. 'Create good atmosphere': Mr. Doni's Story
}

"In our family, we have a unique habit, that is storybook reading. Since my son is in his four years old, I drill him English vocabularies. For the activity itself, we sometimes had both online or offline (printed) books. My son does have a full of enjoyment while storybook reading is implemented. We go to buy books at bookstore for at-least once a month. Sometimes he chose his own storybooks and sometimes the parents did. As an example, we had this book entitled My First Vehicles which is published by Bookcli. The target of this implementation is to gain engagement to the child to promote his English vocabulary acquisition, such as the vehicles names and other vocabularies."

\begin{abstract}
"During the implementation of storybook reading, I try to create a good atmosphere, thus my son will enjoy the moment of listening the stories. To prepare a good atmosphere, first parents can prepare the genre of the book. Children usually had their own favorite things. It can be narrative story or information story. In my case, my son adores vehicles. Thus I choose information story. Second, choose a colorful and interactive books for the children. Thus I choose a book about vehicles which also consist of embossed picture. The existence of embossed picture helps my son to understand and remember the vocabulary better. Third, parents need to fully involved in the reading activity, giving feedback, giving questions, giving praise, or even giving correction. This kind of interaction during the implementation of English storybook reading help my son to keep engaging with me and creates new English vocabulary acquisition."
\end{abstract}

Who.

Participant (Mr. Doni) is the main figure of this story. The participant tried to figure out his roles and awareness of storybook reading activity to his early age son (four years old). Mr. Doni has high interest in developing his child's early English vocabulary acquisition. He thinks that learn English from the very beginning of the stage will give many benefits. One of the benefits is for the children's future needs. The other thing that is important is because of the children's golden ages. Four years old is still in the golden age when the child will have a much easier in receiving the new knowledge or new vocabularies.

Where.

Participant (Mr. Doni) did the storybook reading in two places. He mostly did storybook reading at home. Sometimes he did at book-store while shopping for books.

When.

Participant (Mr. Doni) mostly implemented the English storybook reading activity every day, especially before his child is sleep. He usually uses printed books or offline books to support the activity.

\section{2. 'Create habit in children's golden ages': Mrs. Fatima's Story}

"I personally think that children need to know the reading activity start from three years old, for both Bahasa and English. Children at age three to five years old which is at their golden ages will get easier way in acquiring the new vocabularies, 
especially in English. Pictures inside the book will also help the children to memorize the new vocabularies better."

"I think parents take a big role in introducing English. Especially when the parents have habit to talk in English with the children, it can be a really good habit for them. Parents need to give exposure, so the children will happily actively learn English in their early ages. It is an important thing to do a read together between parents and children. Children will get bored easily when they read by themselves. But when they read with the parents, they become more excited."

"Create habit will come great when parents can create good atmosphere with the children. Children in this early ages need assistance from the adult. This kind of assistance will show if there is an engagement or not. Parents who seriously guide their children will have a big chance to create good impact to their children. I've tried it myself that my children always got excited during storybook reading. This engagement is closely related to the interactions between parents and children."

Who.

Participant (Mrs. Fatima) is the main figure of this story. The participant tried to figure out his roles and awareness of storybook reading activity to his early age daughters (three and five years old). Mrs. Fatima has high interest in developing her children's early English vocabulary acquisition. She thinks that learn English from the very beginning of the stage will give many benefits. One of the benefits is for the children's future needs. The other thing that is important is because of the children's golden ages. Three to five years old are still in the golden age when the child will have a much easier in receiving the new knowledge or new vocabularies.

\section{Where.}

Participant (Mrs. Fatima) did the storybook reading mostly at home. Because she lives in rural area which is quite difficult to find public library. Thus she did the English storybook reading at home.

\section{When.}

Participant (Mrs. Fatima) mostly implemented the English storybook reading activity every day, especially before her children are sleep. She implemented this activity as a habit. She believes that good habit will create good outcomes.

\section{Discussion}

The engagement between parents and children during the implementation of storybook reading can be measured from children's attentiveness, maternal interventions to control the child's behavior and child's responsiveness (Bus \& Van ljzendoorn, 1997). Thus, if adults fail to create engagement during storybook reading activity, children become less attractive. During the interaction, parents usually create feedbacks to keep engaging with the children in build up the interactive one. The maternal evaluative feedback such as giving praise when the children put their full concentration on books, giving advice about the plot, and even giving criticism to give a good moral value to the 
children are ways to build up the engagement between parents and children (Baker, 2001).

Parents begin choosing the genre of the books for the children. As Saracho (2018) suggests that there are two kinds of genres that parents can use in implementing storybook reading to their young children: narrative and information books. Both narrative and information books usually contain good plot of story which shows good moral value for children to learn. The existence of picture storybooks helps the children to memorize the new vocabularies while listening to their parents.

Related to the vocabulary acquisition during storybook reading, parents need to ensure that the children can follow the plot well, because by understanding the stories, it promotes the vocabulary acquisition of second language learners (Elley1989, 2013). When children are listening to stories, children grow their vocabulary development and other areas of literacy (Elley1989, 2013). When children were scaffold by adult during the storybook reading activity, children gain their English vocabulary acquisition (Lambert, 1991). In addition, young children might found many unfamiliar structure of the text or new foreign vocabulary, thus they need adult's assist to build the bridge or to overcome the gap between their own world and what presented in the storybook (Bus, 2003).

This scaffolding by parents not only create a good engagement with the children, but also give good outcomes in developing children's new vocabulary, specifically in English. The preparation the parents make before the implementation, scaffolding during the implementation, giving feedbacks to check children's understanding and response are creating good engagement between parents and children which will affect the children's new vocabulary acquisition.

Parents who wants to create good engagement should give their focus on the interactions happen during the implementation. Parents give praise to the children when children answer the questions correctly, parents choose the theme that the children might interested in, parents give correction when children make mistakes are the example of creating a good engagement (Baker, 2001).

Table 2. Maternal Evaluative Feedback (Baker, 2001)

\begin{tabular}{l|l}
\hline & \multicolumn{2}{c}{ Maternal Evaluative Feedback } \\
\hline Praise : Comments & Parents: Wow, good job! That's right! \\
\hline Praise : Gesture & $\begin{array}{l}\text { Parents: Clap their hands when children get the answer } \\
\text { right }\end{array}$ \\
\hline $\begin{array}{l}\text { Advice } \\
\text { suggestion }\end{array}$ & Parents: Is this good if the rabbit stole the carrot? \\
\hline
\end{tabular}

Table 3. Maternal Miscue Feedback (Baker, 2001)

Maternal Miscue Feedback

\begin{tabular}{l|l}
\hline \multirow{2}{*}{ Ask children to try again } & \begin{tabular}{l} 
Parents: Can you repeat after me? Fire truck. Fire. Truck. \\
\cline { 2 - 2 }
\end{tabular} \\
\cline { 2 - 2 } & Phild : Fair. \\
\cline { 2 - 2 } & Child : : Fire. \\
\hline
\end{tabular}


Table 4. Child Engagement (Baker, 2001)

\begin{tabular}{l|l}
\hline \multicolumn{2}{l}{ Child Engagement } \\
\hline Child : Behavior & Enjoyment: Full focus on the activity. \\
\cline { 2 - 2 } & $\begin{array}{l}\text { Interest: Follow how parents spell some } \\
\text { vocabularies. }\end{array}$ \\
\cline { 2 - 2 } & Positive comments: I really like this book. \\
\cline { 2 - 2 } & $\begin{array}{l}\text { Actions: Ask parents to read the story again } \\
\text { and again. }\end{array}$ \\
\hline
\end{tabular}

\section{Conclusion}

This study discusses the engagement of parents and their children during the implementation of storybook reading to promotes the children's English vocabulary acquisition. This study explores how the parents build up the engagements during the interactions with their children. The findings of study revealed that parents need to create good atmosphere to support the engagement with the children. Without the existence of engagement, children will not acquire new vocabularies because there is no interest. Adults' assistance is really important in building up the engagement. If it is only read without any guidance or interactions, children will not get attractive to the story.

Based on the findings of the study, it is suggested that parents need to make good preparation before the implementation, create good atmosphere during implementation, and keep the children's focus on the story by giving good interactions (For example giving questions). Besides that, the government should give more socialization and care to Indonesian parents in order to build the good habit from home-based family program. Home-based family program in children's golden ages give many benefits to children's future need, specifically in English need. It also good for children's preparation before entering the formal school.

In this study, the number of participants are limited. Therefore, further researchers possibly conduct research with greater number of participants. It is also suggested to conduct research from parents' different background knowledge and their interest on reading storybooks to their children.

\section{References}

Baker, L., Mackler, K., Sonnenschein, S., \& Serpell, R. (2001a). Parents' interactions with their first-grade children during storybook reading and relations with subsequent home reading activity and reading achievement. Journal of School Psychology, 39, 4157438.

Baker, L. (2003). The role of parents in motivating struggling readers. Reading and Writing Quarterly, 19(1), 87-106. https://doi.org/10.1080/10573560308207

Barkhuizen. (2014).

Bus, A. G., \& Van ljzendoorn, M. H. (1997). Affective dimension of mother-infant 
picturebook reading. Journal of School Psychology, 35(1), 47-60.

https://doi.org/10.1016/S0022-4405(96)00030-1

Elley, W.B.(1980). A comparison of content-interest and structuralist reading programs in Niue primary schools. New Zealand Journal of EducationalStudies, 15, 39-53.

Elley, W. B., \& Mangubhai, F. (1983). The Impact of Reading on Second Language Learning. Reading Research Quarterly, 19(1), 53. https://doi.org/10.2307/747337

Elley1989. (2013). to stories. 24(2), 174-187.

Kiefer, B.Z. (2004). Children's literature and children's literacy: Preparing early literacy teachers to understand the aesthetic values of children's literature. In O.N. Saracho \& B. Spodek (Eds.), Contemporary perspectives on language policy and literacy instruction in early childhood education (Vol. v, pp. 161-180). Greenwich, CT: Information Age.

Saracho, O. N. (2016). Research, policy, and practice in early childhood literacy Research, policy, and practice in early childhood literacy. Early Child Development and Care, $0(0), 1-17$.

https://doi.org/10.1080/03004430.2016.1261512

Saracho, O. N. (2018). The social practice of parents 'storybook reading : a critical discourse analysis discourse analysis. Early Child Development and Care, O(0), 1-22. https://doi.org/10.1080/03004430.2018.1498091

Saracho, O. N., \& Spodek, B. (2010). Parents and children engaging in storybook reading. Early Child Development and Care, 180(10), 13791389. https://doi.org/10.1080/03004430903135605 